\title{
Developing a Taxonomy for Identifying Stakeholders in National ICT Policy Implementation
}

Frank Makoza, Cape Peninsula University of Technology, South Africa

https://orcid.org/0000-0002-5818-3810

\begin{abstract}
Information and communication technology (ICT) policies attract different stakeholders in the policy cycle phases. Whilst most studies on stakeholder analysis focuses on identifying stakeholders at the beginning of the policy process (ex-ante), we argue that stakeholders may change during the course of the policy process and hence the need to review previous policy stakeholders and identify new stakeholders in the subsequent phases of the policy process. The article proposes a taxonomy of ex-post stakeholder identification for ICT policy implementation phase. The taxonomy comprises the following steps for identifying stakeholders: categorise policy goals, list stakeholders, decide on stakeholders, categorise stakeholders, assign roles to stakeholders, highlight participation of stakeholders, manage stakeholders, and evaluate stakeholders. The taxonomy may be used by those responsible for recruiting stakeholders in the ICT policy implementation.
\end{abstract}

\section{KEYWORDS}

ICT Policy, Policy Implementation, Stakeholders, Taxonomy

\section{INTRODUCTION}

National information and communication technologies (ICT) policies are now part of the socioeconomic development agendas of developing countries (Duncan, 2015; Hanafizadeh, Khosravi, $\&$ Badie, 2019). When implementing national ICT policies, ensuring the participation of the right stakeholders to support the policy activities is a challenging question (Calandro, Gillwald \& Zingales, 2013; Janssen, \& Helbig, 2018). Stakeholders, in this context, are individuals or organisations that have an interest, influence, engaged and affected by the policy (Elgin \& Weible, 2013; Freeman, 1984). Examples of ICT policy stakeholders include government officials, private sector organisations, international development agencies, legislators, non-government organisations, local ICT associations and policy beneficiaries (Makoza \& Chigona, 2016). The stakeholders perform different roles in the policy process including financing policy programs, making policy decisions, regulating the sector, provide technical expertise, executing policy programs, processes and participate in politics (Brasil, \& Capella, 2017; Luyet, Schlaepfer, Parlange \& Buttler, 2012; Munyua, 2016). Identifying stakeholders is significant to ensure that there is a right match between capacity and policy implementation activities to deliver the expected policy outcomes (Checchi, Loch, Straub, Sevcik, \& Meso, 2012; Villanueva-Mansilla, 2016). 
National ICT policy, like any public policy, follows a set of iterative steps or phases and these include problem identification, agenda setting, enacting of laws, policy implementation and policy monitoring and evaluation (Aviram, Cohen, Beeri, 2019; Lubua \& Maharaj, 2012). Identifying stakeholders is an inherent activity in the phases of the policy cycle. Policy custodians e.g. Government officials specify the type of policy stakeholders to recruit, identify their interests, analysing the influence of policy stakeholders and assign their roles to the policy processes and programs. Interviews, documents, brainstorming and snowball are used to identify the stakeholders (Ballejos \& Montagna, 2008; Mehrizi, Ghasemzadeh \& Molas-Gallart, 2009; Villanueva-Mansilla, 2016). While there is diversity in approaches of identifying stakeholders in literature (see Archterkamp \& Vos, 2007; Bryson, 2004; Luyet et al., 2012; Reed, 2008), it is argued that most of the approaches focus on identifying policy stakeholders at the beginning of the policy process (ex-ante) (see Checchi et al., 2012; Labelle, 2005; Villanueva-Mansilla, 2016). Often policy stakeholders are identified during agenda-setting with limited focus on the subsequent phases of the policy cycle. However, each policy cycle phase has different activities that require different capabilities of stakeholders to achieve the policy goals. There is limited understanding of how stakeholders are identified in the other policy cycle phases (Howlett, McConnell \& Perl, 2016; Janssen \& Helbig, 2018). This study seeks to address part of this knowledge gap and focused on the policy implementation phase.

The objective of this paper is to outline a taxonomy for identifying policy stakeholders in the implementation phase of the national ICT policy based on literature. Drawing a taxonomy development method by Nickerson, Varshney and Muntermann (2013), the study attempts to provide structured information that can be used to identify stakeholders that are more appropriate for the national ICT policy implementation phase. This was important because the policy implementation phase involves translating policy intentions into activities that address policy goals (Jann \& Howlett, McConnell \& Perl, 2016; Wegrich, 2007). Scholars have noted that participation of stakeholders in ICT policy implementation is crucial (Checchi et al., 2012; Duncan, 2015; Kamba, 2013; Mashinini, 2008) but studies on identifying stakeholders in the context of national ICT policy are have received limited attention. Understanding the process of identifying stakeholders may serve to inform policy custodians to select appropriate stakeholders that can contribute towards the success of ICT policy implementation. Researchers can also extend the proposed taxonomy to further understand the process of identifying stakeholders in the context of national ICT policy.

The rest of the paper is presented as follows. Section 2 presents the background to the study. Section 3 summarises the approach used in developing the taxonomy. Section 4 summarises the taxonomy of ICT policy implementation stakeholders. Section 5 discusses the proposed taxonomy and the conclusions drawn from the study.

\section{BACKGROUND TO THE STUDY}

\subsection{Participation of Stakeholders in Policy Process}

Issues of inclusion of stakeholders in the policy process have received attention in the literature (Brasil, \& Capella, 2017; Brugha \& Varvasovszky, 2000; Reed, 2008; Munyua, 2016). The literature highlights the benefits and challenges of participation of stakeholders in the policy process. Some of the benefits of participation of stakeholders in policy include better decision-making where stakeholders agree on issues leading to buy-in of policy goals, support for different opinions and interests on policy goals and means of achieving them; and participation provide and means of social learning where ICT policy experts can learn from policy beneficiaries and vice versa (Blomkamp, 2018; Luyet, Schlaepfer, Parlange \& Buttler, 2012; Pahl-Wostl, 2002). Nonetheless, others maintain that the process of participation can be time-consuming to arrive at decisions, challenges of reconciling the differences in knowledge between experts and non-experts, some stakeholders may dominate other stakeholders leading to some stakeholders being frustrated with the policy activities. Further, delays in 
coming up with policy decisions during participation can be costly (Cooke \& Kothari, 2001; Reed \& Curzon, 2015; Reed, Graves, Dandy et al., 2009). It is, therefore, necessary for the policy custodians to be cautious of the benefits and challenges of participation of stakeholders in the policy process.

\subsection{Identifying Stakeholders in Policy Process}

The processes of participation of stakeholders involve identifying the stakeholders that can contribute towards the successful outcomes of policy activities. Specific to the context of national ICT policy, there is substantial literature that highlight identification of stakeholders as part of the policy process (Chacko, 2005; Checchi et al., 2012; Labelle, 2005). However, in some cases, there is no explicit description of steps in identifying the stakeholders. This leaves a gap in knowledge for understanding the difference between identifying stakeholders and analysing stakeholders. Poel, Kool and van der Giessen (2010: 25) posit that "the identification and analysis of stakeholders are two separate steps" in the policy process. Stakeholder's identification relates to establishing organisations or individuals that are affected by a policy, their interests, behaviour and history (Bailur, 2006). Stakeholder's analysis is the processes of assessing the roles of stakeholders and analysing the influence of policy stakeholders that are linked together in a policy process (Mehrizi, Ghasemzadeh \& Molas-Gallart, 2009).

Lessons can be drawn from studies that have highlighted the steps for identifying stakeholders in the context of projects and initiatives that can form part of the policy implementation process (Ashraf \& Hoque, 2016). For instance, Bryson (2004) suggest the stakeholder's interests and influence matrix. The process begins with brainstorming to come up with a potential list of stakeholders. The list of the stakeholders is analysed to note the stakeholder's performance and their expectations. Key issues of the stakeholders are identified. This is followed by examining the capacity and needs of the stakeholders. Power, legitimacy and capacity are identified and used to rank the stakeholders (Bryson, 2004).

Bailur (2006) suggest three steps of identifying and managing stakeholders for ICT4D projects. The process begins with conducting interviews with potential stakeholders and use maps and diagrams to select the stakeholders. The second step is to outline the behaviour of the stakeholders with the key activities for the project. The third step is to identify the responsibilities and stakeholders to be informed, consulted, involved and controlled. Once the stakeholders have been identified they are managed throughout the project (Bailur, 2006).

Archterkamp and Vos (2007) posit that the process of identifying stakeholders begins with defining the policy goals and what needs to be achieved. The process may use brainstorming techniques with possible parties to be involved in the policy. The potential stakeholders that are identified should be assigned roles that can be passive, active, served, decision-maker, designers, contributors and representatives. In addition, activities for achieving policy goals should be established in phases such as initial/development, performance, implementation and maintenance. It is necessary to determine the policy activities, the focus of activities and the people or organisations involved in the policy (Archterkamp \& Vos, 2007). Table 1 highlights stakeholder's identification steps in the context of policy and initiatives.

Reed et al., (2009) outlined three steps of identifying stakeholders including identify stakeholders; differentiate and categorise stakeholders; and relationships between stakeholders. Policy activities are selected and people or experts in the activities are noted. Using a checklist, the stakeholders are categorised indicating those affected by the actions and problems. The stakeholders are classified according to the effects of functions in relation to ownership or access to resources, their interests and influence (Reed et al., 2009).

Another approach begins with composing a list of stakeholders that include experts on the policy (Poel, Kool \& van der Gressen, 2009). The stakeholders on the list are categorised based on the context of the policy issue. The categories are considered based on the understanding of the policy issues from a different point of views. The classification of the stakeholders focuses on the policy problem instead of actual individuals and organisations. The groups or organisations are selected after 
Table 1. Summary of steps for identifying stakeholders

\begin{tabular}{|l|l|}
\hline Author(s) & Steps \\
\hline Bryson, 2004 & $\begin{array}{l}\text { Identify the stakeholders and their interests; classify the stakeholders; } \\
\text { Identify key issues, coalition support or opposition; analyse influence of each stakeholder; and } \\
\text { rank the stakeholders according to importance }\end{array}$ \\
\hline Bailur, 2006 & Identify stakeholders; understand the behaviour of stakeholders; and manage the stakeholders \\
\hline $\begin{array}{l}\text { Archterkamp \& Vos, } \\
2007\end{array}$ & Define goals; individual brainstorming; roles of involvement; and phasing roles of involvement \\
\hline Reed et al., 2009 & $\begin{array}{l}\text { Identify stakeholders; differentiate and categorise stakeholders; and relationships between } \\
\text { stakeholders }\end{array}$ \\
\hline $\begin{array}{l}\text { Poel, Kool \& van } \\
\text { der Giessen, 2009 }\end{array}$ & $\begin{array}{l}\text { Create a list of stakeholders; and identify stakeholders; study the policy issues; identify types of } \\
\text { stakeholders; identify organisations and individuals; and check for the comprehensiveness }\end{array}$ \\
\hline Andre et al., 2012 & $\begin{array}{l}\text { Specify stakeholders type; specify stakeholders roles; select stakeholders; associate stakeholders } \\
\text { with roles; and analyse the influence and interests }\end{array}$ \\
\hline $\begin{array}{l}\text { Luyet et al., 2012 } \\
\text { Stakeholders identification; stakeholders characterisations; stakeholders structuration; choice of } \\
\text { participation; implementation; and evaluation }\end{array}$ \\
\hline $\begin{array}{l}\text { Aapaoja \& } \\
\text { Haapasalo, 2014 }\end{array}$ & $\begin{array}{l}\text { Define project and customers; stakeholders identification based on functional role; assess } \\
\text { stakeholder silence and impact; classify and prioritize stakeholders and team formation }\end{array}$ \\
\hline $\begin{array}{l}\text { Reed \& Cruzon, } \\
2015\end{array}$ & $\begin{array}{l}\text { Create a list of stakeholders; identify stakeholders using snowball; categorise the stakeholders; } \\
\text { analyse the relationships between stakeholders }\end{array}$ \\
\hline $\begin{array}{l}\text { Colvin, Witt, \& } \\
\text { Key informants and snowballing; use of media; geographical foot print; interests and influence; } \\
\text { intuition; past experiences; stakeholders self-selection }\end{array}$ \\
\hline
\end{tabular}

consideration of many perspectives of the problems and to ensure that all stakeholders are included based on the value chain (Poel, Kool \& van der Gressen, 2009).

Luyet et al. (2012) suggest identifying stakeholders based on context, resources, influence, power, attitudes and potential collaborations. The stakeholders are assigned a degree of participation e.g. inform, consult, collaborate and empower. The means of participation are usually based on communication and decision making. Rules of communication among the stakeholders are considered. Outcomes of the process are examined to understand the process of identifying the stakeholders (Luyet et al., 2012).

Andre et al. (2012) highlighted types of stakeholders based on functions, knowledge, abilities, location and hierarchies. The stakeholders can be identified based on their roles e.g. providers, supporters, coordinators, implementers, beneficiaries etc. The roles can be matched with the responsibilities of the stakeholders, individuals and organisations affected and supporters of the policy. The identified roles can also be used to highlight the stakeholders that are involved in the policy. The interest and influence of the stakeholders can be examined to establish the outcomes of the process (Andre et al, 2012).

From the examples highlighted in Table 1, it is observed that there is a diversity of techniques for identifying stakeholders. The different techniques include brainstorming; interviews and snowball are used to identify policy stakeholders. However, there is still limited distinction of application of the techniques in identifying stakeholders for each a specific policy phase (e.g. policy agenda setting, formulation, enacting of laws, implementation and evaluation). In most cases, policy stakeholders are identified at the beginning of the policy cycle during the policy agenda-setting phase to identify policy problems and set policy objectives. The policy custodians may retain or recruit new stakeholders after the agenda-setting phase (Checchi et al., 2012; Labelle, 2005; Howlett, McConnell \& Perl, 2016). However, there is a gap in understanding on how stakeholders are identified in the subsequent phases of the policy cycle (e.g. enacting of laws, policy implementation and policy evaluation) because each 
policy cycle phase require different roles of stakeholders, resources to carry out the policy processes and programs, managing the different interests, motivations and values of the stakeholders (Brasil \& Capella, 2017; Luyet et al., 2012; Mehrizi et al., 2009). This study concentrates on the implementation phase of the policy cycle and is summarised in the next subsection.

\subsection{Policy implementation (programs, processes and politics)}

Policy implementation is the process of executing policy activities using resources to achieve policy goals (Jann \& Wegrich, 2007). The process involves establishing meaning from policy declarations, identifying activities, allocate resources (e.g. finance, human capacity, legal resources, information and leadership) to activities and execution of the activities through processes, programs and politics (Howlett, McConnel \& Perl, 2016; Marsh \& MacConnel, 2010). Processes are administrative routines and procedures that are carried out in the policy implementation agencies to enforce, prohibit or regulate sector activities which address policy goals (Dovers \& Hezri, 2010). For example, Telecommunications regulations processes can include registration of telecom operators, monitoring of the quality of services and resolving disputes among sector organisations, enforcing universal access obligations for the telecom operators, supporting consumer protection activities and coordination of other policy activities (Gillwald, 2005; Mwakatumbula, Moshi, \& Mitomo, 2019).

Policy programs are specific policy activities that are tied to national budget allocations, addressing specific policy goals that are related to the national development and have specific timeframes and outcomes (Poel \& Kool, 2009). Examples of policy programs are ICT infrastructure projects such as national broadband networks, rural community access projects e.g. telecentres and Internet international gateway connectivity projects e.g. virtual landing points for connection to undersea cables and ICT skills development programs (Schmid, 2009; Villanueva-Mansilla, 2016). Politics are the process of negotiating and prioritising policy implementation of activities by those in political positions in government to secure support from the electorate (Dovers \& Hezri, 2010; Marsh \& MacConnel, 2010). For example, politicians represent the interests of the countries when ratifying international and regional treaties related ICTs, trade and development. The politicians are important in lobbying for support on development at the global level and attracting foreign direct investments. In addition, the politicians formulate and debate on laws that affect the implementation of national ICT policy, set priorities on which policy programs to implements and allocation of resources through national budgets. Politicians are also engaged in oversight of ICT policy implementation activities to ensure transparency and accountability of the funds allocated to the implementation agencies and policy programs (Lindquist, 2006; Makoza, 2019).

There is substantial literature on the implementation of national ICT policy that has highlighted the problem of lack of engagement of stakeholders (e.g. Adeyeye \& Iweha, 2006; Kamba, 2014; Mashinini, 2008). In some cases, stakeholders participate in policy formulation activities but not in the policy implementation activities. Part of the reasons is that the policy stakeholders do not have the specific skills required for the execution of policy programs. Other stakeholders resent the policy implementation process because they were not engaged in policy formulation. The excluded stakeholders may feel that policy implementation activities do not represent their interests and expected policy outcomes. Further, there are tensions among the stakeholders due to differences in the interpretation of policy goals and the means for achieving the goals (Adeyeye \& Iweha, 2005; Twaakyondo, 2011). While extant literature highlight challenges related to stakeholders in policy implementation, there is still limited understanding of how stakeholders are identified beyond the agenda-setting phase of the policy cycle (Howlett, McConnell \& Perl, 2016). This study attempts to propose a taxonomy for identification of stakeholders in the context of ICT policy implementation. 


\section{APPROACH FOR DEVELOPING A TAXONOMY}

Classification schemes help researchers to order information and knowledge in a given area or theme (Varshney, Nickerson, \& Muntermann, 2013). Things of interest in a phenomenon can be categorised using a classification scheme in form of a taxonomy or typology (Doty \& Glick, 1994). The terms typology and taxonomy are often used interchangeably in literature. For clarity, this study will use the term taxonomy as the process of ordering entities or concepts into groups or classes based on similarities that can be used explain a process or a system (Bailey, 1994; Varshney et al., 2013). From the definition, taxonomies provide a structure and organisation of knowledge in a particular theme and can be used to analyse concepts and their relationships (Glass \& Vessey, 1995).

There are many different approaches used in developing a taxonomy and the process has been acknowledged to be complex (Nickerson et al., 2013). For example, taxonomies can be developed based on characteristics and statistical techniques are used to cluster concepts. Another approach is examining the relationships of concepts or organisms over time. While approaches for developing taxonomies can be viewed based on characteristics and relationships, Bailey (1994) suggest that taxonomies can be developed using deductive and inductive approaches. In a deductive approach, the researcher develops a taxonomy from a theory focusing on dimensions and characteristics. In an inductive approach, an empirical case is observed to establish dimensions and characteristics of a taxonomy (Bailey, 1994).

Nickerson et al. (2013) propose a method of developing a taxonomy drawing from deductive and inductive approaches. The iterative process (where dimensions and characteristics can be added or eliminated) began with determining characteristics of the object or concept of interest. Examples of characteristics of policy can be a policy problem or policy goals. The characteristics of an object or concept can be selected based on the purpose of the taxonomy. The ending conditions determine when to terminate the process of developing a taxonomy usually when the characteristics of a concept have been adequately developed. The subjective condition includes a taxonomy which is concise, robust, comprehensible, extendable and explanatory. The objective conditions include representative sample, impact of changes on the objects classified under characteristics, no new characteristics added in the last iteration, each characteristic being unique and when new dimensions or characteristics do not emerge during the analysis (Nickerson et al., 2013; Varshney et al., 2013).

As can be seen in Figure 1, taxonomies can be developed using two approaches and these are empirical to conceptual (E2C) and conceptual to empirical (C2E). In E2C approach, objects or concepts to be classified are identified and common characteristics noted. The characteristics are grouped into dimensions. In $\mathrm{C} 2 \mathrm{E}$ approach, the process begins with conceptualising the dimensions without the objects or concepts. The dimensions must contain characteristics that must be logical sequences of the meta-characteristics (Varshney et al., 2013). The study followed the C2E of the taxonomy development method (Nickerson et al., 2013) to develop a taxonomy that can be used to identify stakeholders in the ICT policy implementation phase. The process was iterative. Literature on national ICT policy implementation sourced from online publications databases were used in the conceptualisation of each dimension of the taxonomy. Concept-centric approach (see Webster \& Watson, 2002; Fisch \& Block, 2018) were considered where the focus was on developing an indepth understanding of the concepts using literate on ICT policy implementation. This approach was consistent with similar studies that have used the taxonomy development methods (see Caroli, Fracassi, Maiolini, \& Carnini Pulino, 2018; Cledou, Estevez, \& Barbosa, 2018). The E2C was not considered in the analysis and left for further studies to validate the proposed taxonomy. The context of the taxonomy was the national ICT policy implementation phase.

\section{SUMMARY OF THE TAXONOMY OF ICT POLICY IMPLEMENTATION STAKEHOLDERS}

Step 1: Meta-characteristic: Recruit stakeholders for the national ICT policy 


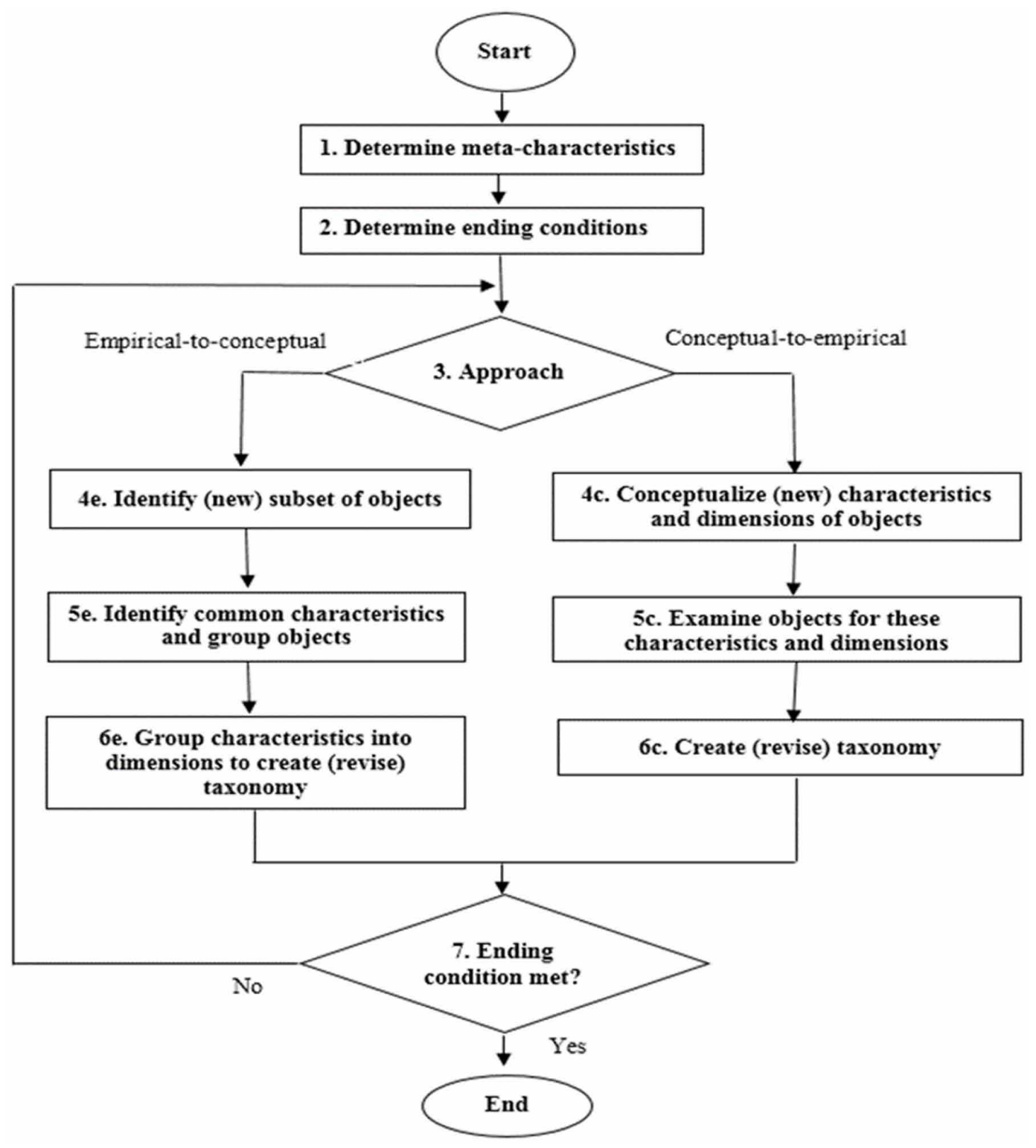

Step 2: Ending condition: Concise, inclusive, comprehensible, extendable taxonomy of policy stakeholders

\subsection{Iteration 1}

Step 3: E2C Approach

Step 4: Identifying nature of national ICT policy goals in literature

Policy goals guide what can be achieved to address social problems. The policy goals of national ICT policy can be short-term and long-term (Srivastava, Verma \& Tripathi, 2017). Time dimension to the national ICT policy goals is significant because of the frequent changes in technology e.g. changes in size, processor speed, hardware and software (Sein \& Harindranath, 2004; Jorgenson \& Vu, 2016). 
Hence, short-term goals address the immediate issues and processes in policy implementation. For example, legal processes, regulations and ICT standards. Further, administrative issues in policy implementation can be addressed through short-term goals (Cohen et al., 2002). The long-term goals for the national ICT policy deal with the issues beyond public organisations and issues that have implications for other economic sectors. For example, ICT infrastructure development programs e.g. broadband or undersea cable connectivity that span across countries or continents. Such programs may involve many stakeholders and negotiations over the means of achieving policy objectives. The process related to the programs may include administrative activities that bring together stakeholders in deciding on the allocation of resources and controlling activities. Politics may be a result of negotiations between politicians and other stakeholders in deciding which programs to prioritise and the negotiations on the terms of agreements which are signed as part of the process for the infrastructure projects (Ashraf \& Hoque, 2016; Clark \& Claffy, 2015).

ICT policy implementation involves different levels of society. In most cases, government departments lead in developing a policy which involves identifying the right stakeholders to take part in the policy process. The list of stakeholders can be predetermined using similar policies or part of the prescription for the sponsors of the policy. For instance, donor-funded initiatives in some cases demand the inclusion of certain stakeholders as a means to mitigating resistance and supporting projects buy-in from the stakeholders (Mansell, 2014). Government officials may also engage stakeholders to identify other stakeholders (snowball) for policy implementation. Government officials may interview stakeholders to suggest potential policy stakeholders (Reed et al., 2009; Reed \& Cruzon, 2015).

Step 5: In summary, national ICT policy goals can be:

- Short-term goals addressing the immediate problems

- Long-term goals addressing issues that require long-term actions

In addition, list of policy implementation stakeholders can be generated through:

- Pre-determined list of stakeholders from similar processes

- A list of stakeholders emerged from recommendations of other stakeholders

Step 6: The characteristics are grouped to form the first taxonomy

- Policy goals: short-term and short-term

- List of stakeholders: pre-determined and emerging

T1: \{policy goals (long-term, short-term), list of stakeholders (pre-determined, emerging) \}

Table 2 summarises example of setting goals and list of stakeholders in policy implementation.

Policy programs usually take a long time to be completed. Examples of a policy program include ICT access projects, ICT skills development programs and ICT infrastructure projects (Lal, 2017; Lewis, 2013). The program requires both financial and human capacity. The policy custodians may require to mobilise resources from private investors or obtain loans from local or international lending institutions. The process can also include negotiating the terms of loans or funding. Further, ICT infrastructure can also require legal and regulatory frameworks to guide the application and use of the infrastructure. The process of enacting laws to regulate the use of ICT infrastructure usually take long in the context of developing countries because of issues of local politics and inadequate capacity in articulating technologies issues (Gillwald, 2010). Hence, the policy goals related to programs are long-term in nature to accommodate the legal and regulatory processes. Policy processes are usually short-term and example of policy processes include short-term activities such as registration and licensing of telecom operators, monitoring the quality of ICT services, profit and retail price services regulation (Bauer, 2010; Singh, 2010).

Stakeholders for policy programs can be predefined e.g. assigned to new program activities based on previous related policy programs or activities. For example, ICT policies activities can be related to other policies such as telecommunication policy, media policy and industrial policy (Marcelle, 


\begin{tabular}{|c|c|c|c|c|}
\hline & \multicolumn{2}{|c|}{ 1. List policy goals } & \multicolumn{2}{|c|}{ 2. List stakeholders } \\
\hline $\begin{array}{l}\text { Policy implementation } \\
\text { activities }\end{array}$ & 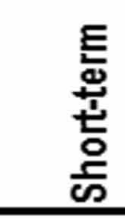 & 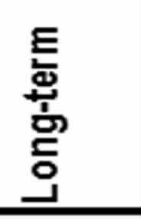 & 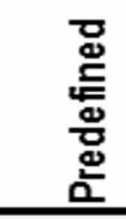 & 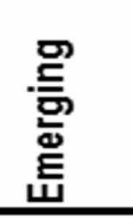 \\
\hline Policy programs & & $x$ & $x$ & \\
\hline Policy processes & $x$ & & & $x$ \\
\hline Policy politics & & & & \\
\hline
\end{tabular}

2000). A list of stakeholders can be drawn from the activities of such policies and the stakeholders to be engaged in the national ICT policy implementation. In some cases, stakeholders can emerge from the ICT sector or other sectors because of the wide application of the ICTs (Mansell, 2014). Potential stakeholders can be interviewed and sometimes other stakeholders can recommend potential stakeholders. The nature of policy activities can also influence how stakeholders are identified. The policy activities are usually not known at the beginning of the policy implementation and require the input of stakeholders who poses expert knowledge or capabilities on the activities (Andre et al., 2012; Reed et al., 2009).

Step 7 Ending conditions: The taxonomy is concise, extendible, sufficiently inclusive and explanatory.

\subsection{Iteration 2}

Step 3: Approach: E2C

Step 4: Identifying decisions inclusion or exclusion of stakeholders in literature

The policy custodians can decide on individuals or organisations to be included and excluded in the policy process. The decision may be based on the nature of resources or influence the stakeholders to contribute towards the policy implementation activities (Mitchell et al., 1997). For example, the decision to include stakeholders may be a result of consideration of funding and technical expertise that the organisations or individuals may provide to the policy activities. In some cases, inclusion may be the result of political influence to get the policy activities to be prioritised in government development agenda. Others have argued that not all stakeholders affected by the policy can be included because of availability of resources and time, expertise and knowledge (Aapaoja, \& Haapasalo, 2014; Ballejos \& Montagna, 2008). In such cases, the exclusion is justified for those who decide on the identification of policy stakeholders.

The decision to select stakeholders who will participate in policy activities can be based on interests, values and potential contributions to the policy activities (Bryson, 2004; Luyet et al. 2012). The decision to exclude stakeholders can be based on legitimacy. For example, laws of the country not allowing those without the political mandate to participate in the policy implementation (Archterkamp \& Vos, 2007; Mitchell et al., 1997).

Step 5: In summary, the decision for selecting stakeholders can be based on 


\begin{tabular}{|c|c|c|c|c|c|c|}
\hline & \multicolumn{2}{|c|}{ 1. List policy goals } & \multicolumn{2}{|c|}{ 2. List stakeholders } & \multicolumn{2}{|c|}{$\begin{array}{l}\text { 3. Decide on } \\
\text { stakeholders }\end{array}$} \\
\hline $\begin{array}{l}\text { Policy implementation } \\
\text { activities }\end{array}$ & 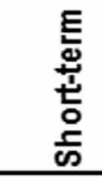 & 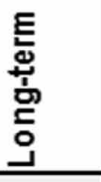 & 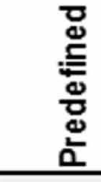 & 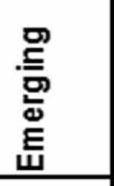 & $\begin{array}{l}\text { 흘 } \\
\text { 을 } \\
\end{array}$ & 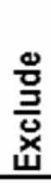 \\
\hline Policy programs & & $x$ & $x$ & & $x$ & \\
\hline Policy processes & $x$ & & & $x$ & & \\
\hline Policy politics & & & & & & $x$ \\
\hline
\end{tabular}

- Inclusion of stakeholders that add value to the policy implementation activities

- Exclusion of stakeholders that do not add value to the policy implementation activities

Step 6: The characteristics are grouped to form the second taxonomy

T2: \{ policy goals (long-term, short-term), list of stakeholders (pre-determined, emerging), decision (include, exclude) $\}$

Policy programs attract different stakeholders that are assigned different roles for the policy implementation activities. Some of the roles can include decision making, providing resources, executing policy activities and coordinating the policy activities (Elgin \& Weible, 2013; Matland, 1995). However, the policy custodians decide on the stakeholders can be included or excluded in the policy programs for ICT implementation. The process of inclusion or exclusion of stakeholders may be based on several factors including knowledge and experience of the policy stakeholders (Luyet al at., 2012), the power, urgency, proximity and legitimacy of the stakeholders (Mitchell et al., 2007) power and interests in the policy programs (Bryson, 2004). Functions of the stakeholders related to policy at different levels of society (e.g., local, regional, national and global) may also influence the inclusion or exclusion of stakeholders (Andre et al., 2012). In some cases, politics as the decisions of stakeholders with political authority can influence the stakeholders that are engaged in policy activities and exclude that stakeholders that have different political interests, agendas or ideas. The excluded stakeholders are perceived to likely undermine the success of policy programs (Meyers \& Vorsanger, 2007; Stahl \& McBride, 2008).

Step 7 Ending conditions: The taxonomy is concise, extendible, sufficiently inclusive and explanatory.

\subsection{Iteration 3}

\section{Step 3: Approach: E2C}

Step 4: Identifying nature of categories for national ICT policy structures

Once the stakeholders have been identified, the next step is to categorise them based on the mode of policy implementation. Policy structures for implementation can be hierarchical and network (Howlett, McConnell \& Perl, 2016; Pulzl \& Treib, 2007). In the hierarchical dimension, implementation of policy activities is usually from the political decision to administrative execution of activities. Hence, few stakeholders are engaged in the process. In the network approach, policy activities emerge from implementation agencies and decisions are collective involving representatives of the stakeholders 
Table 4. Summary of dimensions after iteration 3

\begin{tabular}{|c|c|c|c|c|c|c|c|c|}
\hline \multirow[b]{2}{*}{$\begin{array}{l}\text { Policy implementation } \\
\text { activities }\end{array}$} & \multicolumn{2}{|c|}{$\begin{array}{l}\text { 1. List policy } \\
\text { goals }\end{array}$} & \multicolumn{2}{|c|}{$\begin{array}{c}\text { 2. List } \\
\text { stakeholders }\end{array}$} & \multicolumn{2}{|c|}{$\begin{array}{l}\text { 3. Decide on } \\
\text { stakeholders }\end{array}$} & \multicolumn{2}{|c|}{$\begin{array}{l}\text { 4. Categorise } \\
\text { stakeholders }\end{array}$} \\
\hline & 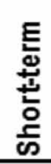 & 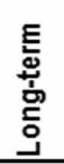 & 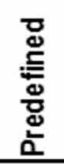 & 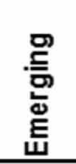 & 帝 & 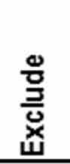 & 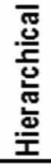 & 总 \\
\hline Policy programs & & $x$ & $x$ & & $x$ & & & $x$ \\
\hline Policy processes & $x$ & & & $x$ & & & $x$ & \\
\hline Policy politics & & & & & & $x$ & & $x$ \\
\hline
\end{tabular}

affected by the policy. The stakeholders may use their resources e.g. finance, information, knowledge, contacts and leadership in the policy activities (Elgin \& Weible, 2013; Weible \& Sabatier, 2007).

The process of organising and bringing together stakeholders based on existing organisational structures can lead to a few stakeholders in making decisions for policy activities (Reed, 2008; Ballejos \& Montagna, 2008). The policy decisions in such cases sometimes may miss out important issues or different opinions on the policy decisions. Collective decision making in policy activities is encouraged where stakeholders from more than two organisations are engaged in the decisions for the policy activities (Brugha \& Varvasovszky, 2000; Reed et al., 2009).

Step 5: In summary, the policy implementation structure can be categorised into

- Hierarchical where policy implementation decisions are made in a top-down manner

- Networked where policy implementation decisions are collective among stakeholders

Step 6: The characteristics are grouped to form the third taxonomy

T2: \{policy goals (long-term, short-term), list of stakeholders (pre-determined, emerging), decision (include, exclude), category (Hierarchical, networked)

Policy programs have normally large stakes beyond public institutional and include the general public and private organisations. Hence, the network approach is ideal where stakeholders are categorised beyond public institutional (Bryson, 2004). The network approach supports the view that policy programs should holistically address social challenges and engaging diverse stakeholders is one way of problem-solving. In contrast, the hierarchical approach of categorising stakeholders concentrates on government or public organisation in implementing policy activities (Andre at al., 2012; Singh, 2010). The program's activities are structured following the chain of command and authority. Politicians and top government officials make decisions are on the policy programs and processes that are executed in the implementation agencies. Other policy stakeholders outside government have limited capacity to influence the policy decisions (Howlett, McConnell \& Perl, 2016; Loblich \& Wendelin, 2012).

Step 7 Ending conditions: The taxonomy is concise, extendible, sufficiently inclusive and explanatory.

\subsection{Iteration 4}

Step 3: Approach - E2C

Step 4: Identifying roles of the stakeholders in ICT policy implementation

The identified stakeholders who form part of the policy actors are assigned roles in the policy implementation activities. The stakeholders can be directly engaged in the execution of policy activities including making decisions, allocating resources to activities and interacting with other stakeholders 
in the policy activities. Other stakeholders can be involved where they may not directly be engaged in the policy activities but influence the decision and direction of the policy activities. Assigning roles to stakeholders that have direct control or influence over the policy activities (Andre et al., 2012; Ballejos \& Montagna 2008). Assigning the role to stakeholders who are not engaged in operational activities but influence decisions that affect the direction of activities (Mitchell, Agle, \& Wood, 1997). Step 5: In summary, the identified roles of policy stakeholders in policy implementation can be categorised into:

- Direct roles: where stakeholders are engaged in decision making, allocating resources

- Indirect involvement: where stakeholders do not directly in policy activities but influence the decisions and policy activities

Step 6: The characteristics are grouped to form the fourth taxonomy

T2: \{policy goals (long-term, short-term), list of stakeholders (pre-determined, emerging), decision (include, exclude), category (Hierarchical, networked), roles (direct, indirect) \}

Stakeholders can perform different roles on policy implementation and the roles include decisionmakers, policy supporters, sponsors, implementers, regulators and those affected by the policy (Andre et al., 2012; Archterkamp \& Vos, 2007). The roles of the stakeholders can also be classified into direct and indirect roles (Checchi et al., 2012). The direct roles involve the execution of policy programs and processes where the stakeholders engaged in the allocation of resources and making decisions or participate in negotiations to influence the policy outcomes (Archterkamp \& Vos, 2007; Matland, 1995). For instance, the role of politicians in prioritising the policy programs for the government to implement in a given period.

Step 7 Ending conditions: The taxonomy is concise, extendible, sufficiently inclusive and explanatory.

\subsection{Iteration 5}

Step 3: Approach - E2C

Step 4: Identifying nature of stakeholder participation in policy implementation A holistic approach to address social challenges using ICT policies requires engagement of stakeholders. Participation of stakeholders in policy implementation happens when the government as custodians of the ICT policy allow individuals or organisations that are affected by the policy to influence the decisions and execution of policy activities (Bryson, 2004; Bridgman \& Davis, 2003). It is perceived that participation of stakeholders supports to address the challenges of policy activities that meet the needs of the policy beneficiaries, promote equity among stakeholders and support transparency, a better understanding of the social issues and improved acceptance of policy decisions (Bryson, 2004; Luyet et al., 2012). In contrast, policy custodian can provide one-way communication and limited

Table 5. Summary of dimensions after iteration 4

\begin{tabular}{|c|c|c|c|c|c|c|c|c|c|c|}
\hline \multirow[b]{2}{*}{$\begin{array}{l}\text { Policy implementation } \\
\text { activities }\end{array}$} & \multicolumn{2}{|c|}{ 1. List policy goals } & \multicolumn{2}{|c|}{$\begin{array}{c}\text { 2. List } \\
\text { stakeholders }\end{array}$} & \multicolumn{2}{|c|}{$\begin{array}{l}\text { 3. Decide on } \\
\text { stakeholders }\end{array}$} & \multicolumn{2}{|c|}{$\begin{array}{l}\text { 4. Categorise } \\
\text { stakeholders }\end{array}$} & \multicolumn{2}{|c|}{$\begin{array}{l}\text { 5. Assign roles to } \\
\text { stakeholders }\end{array}$} \\
\hline & 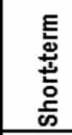 & 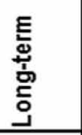 & 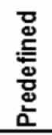 & 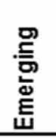 & 흘 & 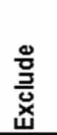 & 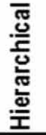 & $\begin{array}{l}\text { 능 } \\
\text { 总 } \\
\text { L्. }\end{array}$ & $\begin{array}{l}\overleftrightarrow{\mathrm{d}} \\
\stackrel{\mathrm{L}}{0}\end{array}$ & 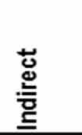 \\
\hline Policy programs & & $x$ & $x$ & & $x$ & & & $x$ & $x$ & \\
\hline Policy processes & $x$ & & & $x$ & & & $x$ & & $x$ & \\
\hline Policy politics & & & & & & $x$ & & $x$ & & $x$ \\
\hline
\end{tabular}


feedback to the policy stakeholders. The approach to participation is symbolic where the stakeholders are fully engaged in the policy implementation decisions and activities (Bridgman \& Davis, 2003). Step 5: In summary, the identified approaches to participation of stakeholders in policy implementation can be categorised into:

- Involvement: where stakeholders are engaged and influence policy decisions

- Symbolic participation: where stakeholders do not influence the decisions and policy activities

Step 6: The characteristics are grouped to form the fourth taxonomy

T2: \{policy goals (long-term, short-term), list of stakeholders (pre-determined, emerging), decision (include, exclude), category (Hierarchical, networked), roles (direct, indirect), participation (involve, symbolic\}

Participation of stakeholders in policy implementation have can have real involvement where all stakeholders have the power to influence the decisions and outcomes of policy programs and processes (Mitchell et al., 1997). In some cases, the participation of stakeholders can be symbolic where the stakeholders with authority or mandate can dominate the decisions for the policy programs and processes. The dominant group may allow other stakeholders to comment or provide feedback on the policy activities but the final decisions are made by the dominating group or individuals (Bishop \& Davis, 2005). A common example is the role of politicians in public policies where they dominate the policy decisions without consideration of the groups that represent the interests of policy beneficiaries (Mashinini, 2008; Singh, 2010).

Step 7: Ending conditions: The taxonomy is concise, extendible, sufficiently inclusive and explanatory.

\subsection{Iteration 6}

Step 3: Approach: E2C

Step 4: Identifying management of stakeholders in literature

Management of stakeholders is the process of controlling and directing the perceptions and beliefs that stakeholders have on the outcomes of the policy activities (Ballejos \& Montagna, 2008; Bryson, 2004). There is a recognition that stakeholders can influence other stakeholders to act and achieve outcomes that are perceived to be of value in the policy activities (Bailur, 2006). Management of stakeholders may use techniques including informing, consulting, partnership and control. In informing the stakeholders share information about policy implementation activities and in consulting the stakeholder obtain feedback that can influence the decision on policy implementation activities. In partnership, the stakeholders collaborate in policy implementation activities. Control is when stakeholders have the capacity to decide and influence policy implementation activities (Bailur, 2006; Bryson, 2004; Eden \& Ackermann, 1998).

Table 6. Summary of dimensions after iteration 5

\begin{tabular}{|c|c|c|c|c|c|c|c|c|c|c|c|c|}
\hline & \multicolumn{2}{|c|}{ 1. List policy goals } & \multicolumn{2}{|c|}{$\begin{array}{c}\text { 2. List } \\
\text { stakeholders }\end{array}$} & \multicolumn{2}{|c|}{$\begin{array}{l}\text { 3. Decide on } \\
\text { stakeholders }\end{array}$} & \multicolumn{2}{|c|}{$\begin{array}{l}\text { 4. Categorise } \\
\text { stakeholders }\end{array}$} & \multicolumn{2}{|c|}{$\begin{array}{l}\text { 5. Assign roles to } \\
\text { stakeholders }\end{array}$} & \multicolumn{2}{|c|}{$\begin{array}{l}\text { 6. Stakeholders } \\
\text { participation }\end{array}$} \\
\hline $\begin{array}{l}\text { Policy implementation } \\
\text { activities }\end{array}$ & $\begin{array}{l}\text { E } \\
\text { \$⿱ } \\
\text { t̀ } \\
\text { क }\end{array}$ & 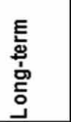 & 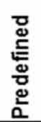 & 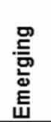 & 莺 & 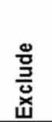 & 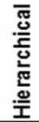 & 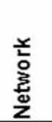 & 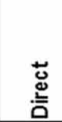 & 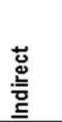 & $\stackrel{0}{\grave{2}}$ & $\begin{array}{l}\text { 응 } \\
\text { 总 }\end{array}$ \\
\hline Policy programs & & $x$ & $x$ & & $x$ & & & $x$ & $x$ & & $x$ & \\
\hline Policy processes & $x$ & & & $x$ & & & $x$ & & $x$ & & $x$ & \\
\hline Policy politics & & & & & & $x$ & & $x$ & & $x$ & & $x$ \\
\hline
\end{tabular}


Step 5: In summary, the identified approaches to managing stakeholders in policy implementation can be categorised into:

- Interests: beliefs and perceptions of stakeholders which influence their actions in policy activities

- Influence: the ability of stakeholders to influence other stakeholders in decisions and actions related to policy implementation

Step 6: The characteristics are grouped to form the fifth taxonomy

T2: \{policy goals (long-term, short-term), list of stakeholders (pre-determined, emerging), decision (include, exclude), category (Hierarchical, networked), roles (direct, indirect), participation (involve, symbolic), manage (interest, influence) $\}$

Policy stakeholders have different interests and power that can determine how policy custodians can manage the policy stakeholders in policy implementation activities. The degree of interests and power can lead to four categories of stakeholders that policy custodian can manage (Bryson, 2004; Colvin, Witt \& Lacey, 2016). The four categories include players, crowd, context setters and subjects. Players are stakeholders that have high-interests and high-power in policy implementation and require to be closely managed e.g., donors or politicians because of their access to resources (Munyua, 2016). The crowd are stakeholders with both low-interests and power in policy implementation and require less effort to be managed e.g. policy beneficiaries. Context setters are stakeholders that have high power but low interests in policy implementation and need to be informed. Subjects are stakeholders that have high-interests but low-power in the policy implementation (Ballejos \& Montagna, 2008).

Policy programs and politics prioritise involvement of players and subjects because these groups of stakeholders have the power to influence the policy activities and can affect the course of decisions and actions for policy implementation (McConnell \& Marsh, 2009). Policy processes are usually routines related to the policy implementation and can involve the crowd and subjects (Luyet et al., 2012) Step 7 Ending conditions: The taxonomy is concise, extendible, sufficiently inclusive and explanatory

\subsection{Iteration 7}

Step 3: Approach: E2C

Step 4: Identifying evaluation of stakeholders in literature

Evaluation of stakeholder is conducted to ensure that relevant stakeholders are retained and new stakeholders to support policy implementation activities (Bailur, 2006; Reed et al., 2009). Evaluation of stakeholders can also be conducted on the outcomes of policy implementation activities. Depending on the outcomes, which can be successful or failure, the policy custodians will examine the policy implementation process to ensure right stakeholders are retained. In some cases, new stakeholders may be recruited to address the identified problems (Bailur, 2006). The results of the policy implementation

Table 7. Summary of dimensions after iteration 6

\begin{tabular}{|c|c|c|c|c|c|c|c|c|c|c|c|c|c|c|}
\hline \multirow[b]{2}{*}{$\begin{array}{l}\text { Policy implementation } \\
\text { activities }\end{array}$} & \multicolumn{2}{|c|}{ 1. List policy goals } & \multicolumn{2}{|c|}{$\begin{array}{c}\text { 2. List } \\
\text { stakeholders }\end{array}$} & \multicolumn{2}{|c|}{$\begin{array}{l}\text { 3. Decide on } \\
\text { stakeholders }\end{array}$} & \multicolumn{2}{|c|}{$\begin{array}{l}\text { 4. Categorise } \\
\text { stakeholders }\end{array}$} & \multicolumn{2}{|c|}{$\begin{array}{l}\text { 5. Assign roles to } \\
\text { stakeholders }\end{array}$} & \multicolumn{2}{|c|}{$\begin{array}{l}\text { 6. Stakeholders } \\
\text { participation }\end{array}$} & \multicolumn{2}{|c|}{$\begin{array}{c}\text { 7. Manage } \\
\text { stakeholders }\end{array}$} \\
\hline & 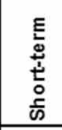 & 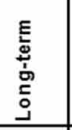 & 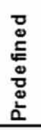 & 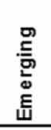 & $\begin{array}{l}\stackrel{0}{0} \\
\frac{\Xi}{0} \\
\underline{\underline{E}}\end{array}$ & 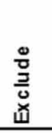 & 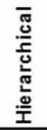 & 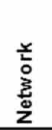 & 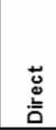 & 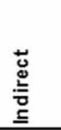 & $\stackrel{0}{\grave{0}}$ & $\begin{array}{l}\stackrel{0}{\circ} \\
\text { E } \\
\text { ઢ }\end{array}$ & 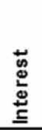 & 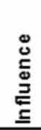 \\
\hline Policy programs & & $x$ & $x$ & & $x$ & & & $x$ & $\mathrm{x}$ & & $x$ & & & $x$ \\
\hline Policy processes & $x$ & & & $x$ & & & $x$ & & $x$ & & $x$ & & $x$ & \\
\hline Policy politics & & & & & & $x$ & & $x$ & & $x$ & & $x$ & & $x$ \\
\hline
\end{tabular}


activities can vary and include positive or negative; success or failure to achieve the policy goals. The results can influence change in policy implementation activities or other phases in the policy cycle (Jann \& Wegrich, 2007). The outcomes of the process for engaging stakeholders in the policy implementation activities (Bryson, Patton \& Bowman, 2011). New forms of activities are taken as a result of the outcomes for engaging policy stakeholders in policy implementation (Luyet et al., 2012; Rowley, 2011).

Step 5: In summary, the outcomes for the process of engaging stakeholders in policy implementation can be categorised into:

- Change: outcomes of engaging stakeholders in policy decisions and activities

- Results: the positive or negative outcomes of the process for engaging stakeholders in policy implementation activities

Step 6: The characteristics are grouped to form the fourth taxonomy

T2: \{policy goals (long-term, short-term), list of stakeholders (pre-determined, emerging), decision (include, exclude), category (hierarchical, networked), roles (direct, indirect), participation (involve, symbolic), evaluate (results, change)\}

Policy programs usually have goals that are long-term in nature. The goals are written-down and referenced to check on the progress of the policy implementation activities (Jann \& Wegrich, 2007; McConnell \& Marsh, 2010). The policy stakeholders assess the policy implementation activities to determine further decisions and action that can lead to achieving policy goals (Hanafizadeh, Khosravi, $\&$ Badie, 2019). For stance, government officials respond to changes in the policy programs to improve the results of the programs. Similarly, policy stakeholders can assess the policy processes and make necessary changes to ensure that the processes can support the achievement of the policy goals. In some cases, changes can be a result of addressing new challenges that have emerged during the policy implementation activities (McConnell \& Marsh, 2010).

Step 7: Ending conditions: The taxonomy is concise, extendible, sufficiently inclusive and explanatory

\section{DISCUSSION OF THE FINDINGS AND CONCLUSION}

The study was set to develop a taxonomy of stakeholders for ICT policy implementation. The model for developing taxonomy (Nickerson et al., 2013) was used to guide the process. The study drew literature on ICT policy and stakeholders analysis to classify objects that were relevant for policy implementation setting. The taxonomy for ICT policy implementation includes the following attributes: policy goals, list of stakeholders, the decision on stakeholders to be engaged, categorising stakeholders, assigning roles of selected stakeholders, the participation of stakeholders and evaluation of stakeholders. The attributes support understanding of organising knowledge that is related to policy programs, processes and processes in the context of ICT policy implementation (Marsh \& McConnell, 2010; Howlett, McConnell \& Perl, 2016).

Table 8. Summary of dimensions after iteration 7

\begin{tabular}{|c|c|c|c|c|c|c|c|c|c|c|c|c|c|c|c|c|}
\hline \multirow[b]{2}{*}{$\begin{array}{l}\text { Policy } \\
\text { implementation } \\
\text { activities }\end{array}$} & \multicolumn{2}{|c|}{$\begin{array}{l}\text { 1. List policy } \\
\text { goals }\end{array}$} & \multicolumn{2}{|c|}{$\begin{array}{c}\text { 2. List } \\
\text { stakeholders }\end{array}$} & \multicolumn{2}{|c|}{$\begin{array}{l}\text { 3. Decide on } \\
\text { stakeholders }\end{array}$} & \multicolumn{2}{|c|}{$\begin{array}{l}\text { 4. Categorise } \\
\text { stakeholders }\end{array}$} & \multicolumn{2}{|c|}{$\begin{array}{l}\text { 5. Assign roles } \\
\text { to stakeholders }\end{array}$} & \multicolumn{2}{|c|}{$\begin{array}{c}\text { 6. Stakeholders } \\
\text { participation }\end{array}$} & \multicolumn{2}{|c|}{$\begin{array}{c}\text { 7. Manage } \\
\text { stakeholders }\end{array}$} & \multicolumn{2}{|c|}{$\begin{array}{c}\text { 8. Evaluate } \\
\text { stakeholders }\end{array}$} \\
\hline & 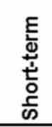 & 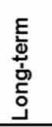 & 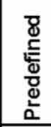 & 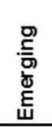 & $\begin{array}{l}\text { 음 } \\
\text { 흠 } \\
\text { 드 }\end{array}$ & $\begin{array}{l}\frac{0}{0} \\
\text { ż̃ } \\
\text { यّ }\end{array}$ & 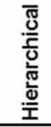 & $\begin{array}{l}\text { 능 } \\
\text { 离 } \\
\text { z }\end{array}$ & 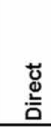 & $\begin{array}{l}\text { t艹 } \\
\text { 늫 } \\
\underline{\underline{\underline{c}}} \\
\end{array}$ & $\stackrel{0}{\stackrel{0}{0}}$ & $\begin{array}{l}\frac{0}{0} \\
\text { है } \\
\text { क }\end{array}$ & 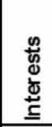 & 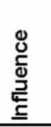 & 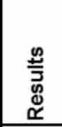 & 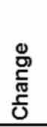 \\
\hline Policy programs & & $x$ & $x$ & & $x$ & & & $x$ & $x$ & & $x$ & & & $x$ & $x$ & \\
\hline Policy processes & $x$ & & & $x$ & & & $x$ & & $x$ & & $x$ & & $x$ & & & $x$ \\
\hline Policy politics & & & & & & $x$ & & $x$ & & $x$ & & $x$ & & $x$ & & \\
\hline
\end{tabular}


While several studies have highlighted the significance of considering stakeholders in ICT policy process (Chacko, 2005; Checchi et al., 2012; Kamba, 2013; Mashinini, 2008), the initial process of identifying the right stakeholders was still missing and the study extends this debate to propose a taxonomy that offers additional way of identifying stakeholders found in literature (e.g. Archterkamp \& Vos, 2005; Andre at al., 2012; Bryson, 2004). For stance, Bailur (2006) suggest conducting interviews and use maps and diagrams to identify and understand the behaviour of stakeholders in the context of ICT for development initiatives. Bryson (2004) outline steps such as brainstorming a potential list of stakeholders to identify their interests and influence while Archterkamp and Vos (2005) indicate definition of goals and identification of possible parties to be involved. Andre et al. (2012) go further to specify the types of stakeholders based on their knowledge, location and function and the roles that the stakeholders can perform. While there is diversity in identifying stakeholders, understanding of identification of stakeholders specific to the ICT policy implementation phase was not clear more specific to activities for policy programs, processes and politics (Howlett, McConnell, \& Perl, 2016).

The contribution of the study is the taxonomy for identifying stakeholders specifically in ICT policy implementation setting. The taxonomy can be useful policy custodians recruiting stakeholders for ICT policy implementations. The policy custodians can consider the different dimensions of the process of setting goals, listing stakeholders, the inclusion of stakeholders, categorising the stakeholders and assigning their roles. The interests and influence of the stakeholders can be articulated to effectively manage the stakeholders. The policy custodians can decide on the participation of stakeholders to include symbolic or involvement of the stakeholders. Results or change in the policy implementation can be highlighted using the taxonomy. Further, the taxonomy provides a better understanding of ICT policy implementation knowledge for scholars. The taxonomy attempted to address the specific needs of the implementation phase. While other studies have suggested consideration of policy activities in identifying stakeholders (Andre et al., 2012; Poel, Kool, \& van der Giessen, 2009; Reed et al., 2009) the findings highlighted the usefulness of categorising of policy the activities into policy programs, processes and politics. The three categories can be compared with policy objectives and the roles of the stakeholders to come up with structures of participation (networked or hierarchical), participation (symbolic or involvement) and managing the interests and influence of policy stakeholders.

Another interesting finding is the consideration of politics as one of the key activities of policy implementation. The findings highlight politics as one of the key activities for ICT policy implementation. This can further support understanding of managing of interests and influence of stakeholders highlighted in previous studies (Aapaoja \& Haapasalo, 2014; Andre et al., 2012; Bryson, 2004; Colvin, Witt, \& Lacey, 2016). The study joins this debate to highlight the role of politics beyond understanding of policy stakeholders interests (individuals or organisations who prioritise on the policy activities because they can benefit or lose) and influence (involvement in the policy activities to bring about the desired change) (Colvin, Witt, \& Lacey, 2016; Duncan, 2015). The findings highlight the importance of those who have the legal mandate (power from laws and regulations) and mandate from the electorate in facilitating the course of actions that can affect the way policy stakeholders are identified. This also shows that national ICT policy implementation is a process that attracts multi-dimensional influences involving many stakeholders beyond government officials and politicians (Blomkamp, 2018; De Bussy \& Kelly, 2010; Munyua, 2016). The taxonomy also highlights dimensions for evaluation that include results and change. This finding was important because most of the time, results (for use of resources and making policy decisions) and outcomes (consequences of actions taken in the policy implementation activities) are noted during the policy evaluation phase (Lubua \& Maharaj, 2012). The study adds to the understanding of evaluating the process of identifying stakeholders.

The taxonomy proposed in the study set a new path for further research for the ICT policy implementation. The study used the taxonomy development method (Nickerson et al., 2013) concentrating on developing a list of information with dimensions for identifying stakeholders. The process followed conceptual to empirical (C2E). There is need to validate the taxonomy especially in 
the context of developing countries where policy implementation has been challenging in delivering the expected policy outcomes (Kamba, 2013; Mashinini, 2008; Twaakyondo, 2011; Villanueva-Mansilla, 2016). Thus, empirical to conceptual approach (E2C) can be followed. Other fruitful investigations could also extend the dimensions of the national ICT policy implementation taxonomy. For instance, further examination of categories of policy stakeholders in networked or hierarchical approach in a specific context. In the context of developing countries, not all countries can apply the networked approach which supports policy actors who share common interests, beliefs and culture. In such cases, the hierarchical approach could be ideal (Stahl \& McBride, 2008; Weible \& Sabatier, 2007).

To conclude, this paper presented a taxonomy for identifying stakeholders in the implementation phase of national ICT policy. The study concentrated on policy implementation activities including policy programs, processes and policies. Key information for the taxonomy includes establishing policy goals, listing the stakeholders, deciding on the inclusion or exclusion of the stakeholders, establish the categories of the stakeholders and assign their roles. In addition, the taxonomy highlights the dimensions for managing, the participation of stakeholders and evaluation of the ICT policy implementation. The taxonomy can be useful for scholars to understand policy implementation activities and for policy custodians in recruiting appropriate policy stakeholders. 


\section{REFERENCES}

Aapaoja, A., \& Haapasalo, H. (2014). A framework for stakeholder identification and classification in construction projects. Open Journal of Business and Management, 2(1), 43-55. doi:10.4236/ojbm.2014.21007

Adeyeye, M., \& Iweha, C. (2005). Towards an effective national policy on information and communication technologies for Nigeria. Information Development, 21(3), 202-208. doi:10.1177/0266666905057337

Andre, K., Simonsson, L., Swartling, A., \& Linner, B. (2012). Method development for identifying and analysing stakeholders in climate change adaptation process. Journal of Environmental Policy and Planning, 14(3), 243-261. doi:10.1080/1523908X.2012.702562

Archterkamp, M., \& Vos, J. (2007). Critically identifying stakeholders. Evaluating boundary critique as a vehicle for stakeholder identification. Systems Research and Behavioral Science, 24(1), 3-14. doi:10.1002/sres.760

Ashraf, M., \& Hoque, R. (2016). An illustration of information communication technology (ICT)-mediated innovation-adoption-implementation in rural Bangladesh. Tékhne (Instituto Politécnico do Cávado e do Ave), 14(1), 45-51. doi:10.1016/j.tekhne.2016.04.003

Aviram, N., Cohen, N., \& Beeri, I. (2019). Wind(ow) of Change: A Systematic review of policy entrepreneurship characteristics and Strategies. Policy Studies Journal: the Journal of the Policy Studies Organization, 0(0), 1-33. doi: $10.1111 /$ psj. 12339

Bailey, K. (1994). Numerical taxonomy and cluster analysis. Typologies and Taxonomies, 34, 24.

Bailur, S. (2006). Using stakeholder theory to analyse Telecenter project. Information Technologies and International Development, 3(3), 61-80. doi:10.1162/itid.2007.3.3.61

Ballejos, L., \& Montagna, L. (2008). Method for stakeholder identification in interorganisational environments. Requirements Engineering, 13(4), 281-297. doi:10.1007/s00766-008-0069-1

Bauer, J. (2010). Learning from each other: Promises and pitfalls of benchmarking in communications policy. Info, 12(6), 8-20. doi:10.1108/14636691011086017

Bishop, P., \& Davis, G. (2002). Mapping public participation in policy choices. Australian Journal of Public Administration, 61(1), 14-29. doi:10.1111/1467-8500.00255

Blomkamp, E. (2018). The promise of Co-design for Public policy. Australian Journal of Public Administration, 77(4), 729-743. doi:10.1111/1467-8500.12310

Brasil, F., \& Capella, A. (2017). Translating ideas into action: Brazilian studies of the role of the policy entrepreneur in the public policy process. Policy and Society, 36(4), 504-522. doi:10.1080/14494035.2017.1 374691

Bridgman, P., \& Davis, G. (2003). What use is a policy cycle? Plenty, if the aim is clear. Australian Journal of Public Administration, 62(3), 98-102. doi:10.1046/j.1467-8500.2003.00342.x

Brugha, R., \& Varvasovszky, Z. (2000). Stakeholder Analysis: A review. Health Policy and Planning, 15(3), 239-246. doi:10.1093/heapol/15.3.239 PMID:11012397

Bryson, J. (2004). What to do when stakeholders matter: Stakeholder identification and analysis techniques. Public Management Review, 6(1), 21-53. doi:10.1080/14719030410001675722

Bryson, J., Patton, M., \& Bowman, R. (2011). Working with evaluation stakeholders: A rationale, step-wise approach and toolkit. Evaluation and Program Planning, 34(1), 1-12. doi:10.1016/j.evalprogplan.2010.07.001 PMID:20674980

Calandro, E., Gillwald, A., \& Zingales, N. (2013). Mapping multistakeholderism in Internet governance: Implications for Africa. Cape Town: Research ICT Africa.

Caroli, M., Fracassi, E., Maiolini, R., \& Carnini Pulino, S. (2018). Exploring social innovation components and attributes: A taxonomy proposal. Journal of Social Entrepreneurship, 9(2), 94-109. doi:10.1080/194206 76.2018.1448296 
Chacko, G. (2005). Paradise lost? Reinstating the human development agenda in ICT policies and strategies. Information Technology for Development, 11(1), 97-99. doi:10.1002/itdj.20005

Checchi, R., Loch, K., Straub, D., Sevcik, G., \& Meso, P. (2012). National ICT policies and development: A stage model and stakeholders theory perspective. Journal of Global Information Management, 20(1), 57-79. doi:10.4018/jgim.2012010103

Clark, D., \& Claffy, K. (2015). Anchoring policy development around stable points: An approach to regulating the co-evolving ICT ecosystem. Telecommunications Policy, 39(10), 848-860. doi:10.1016/j.telpol.2015.07.003

Cledou, G., Estevez, E., \& Barbosa, L. (2018). A taxonomy for planning and designing smart mobility services. Government Information Quarterly, 35(1), 61-76. doi:10.1016/j.giq.2017.11.008

Cohen, G., Salomon, I., \& Nijkamp, P. (2002). Information-communications technologies (ICT) and transport: Does knowledge underpin policy? Telecommunications Policy, 26(1-2), 31-52. doi:10.1016/S03085961(01)00052-0

Colebatch, H. K. (2005). Policy analysis, policy practice and political science. Australian Journal of Public Administration, 64(3), 14-23. doi:10.1111/j.1467-8500.2005.00448.x

Colvin, R., Witt, G., \& Lacey, J. (2016). Approaches to identifying stakeholders in environmental management: Insights from practitioners to go beyond the 'usual suspects.' Land Use Policy, 52, 266-276. doi:10.1016/j. landusepol.2015.12.032

Cooke, B., \& Kothari, U. (2001). Participation: The new tyranny? London: Zed Books.

De Bussy, N., \& Kelly, L. (2010). Stakeholders, politics and power. Journal of Communication Management.

Doty, D., \& Glick, W. (1994). Typologies as a unique form of theory building: Toward improved understanding and modelling. Academy of Management Review, 19(2), 230-251. doi:10.5465/amr.1994.9410210748

Dovers, S., \& Herzri, A. (2010). Institutions and policy process: The means to the ends of adaptation. WIREs Climate Change, 1(2), 212-231. doi:10.1002/wcc.29

Duncan, J. (2015). Debating ICT policy first principles for the Global South: The case of South Africa. Communicatio, 41(1), 1-21. doi:10.1080/02500167.2015.1020821

Eden, C., \& Ackermann, F. (1998). Making strategy. Thousand Oaks, CA: Sage.

Elgin, D., \& Weible, C. (2013). A Stakeholder analysis of Colorado climate and energy issues using Policy analytical capacity and the Advocacy coalition framework. The Review of Policy Research, 30(1), 114-133. doi:10.1111/ropr.12005

Fisch, C., \& Block, J. (2018). Six tips for your (systematic) literature review in business and management research. Management Review Quarterly, 68(2), 103-106. doi:10.1007/s11301-018-0142-x

Freeman, R. (1984). Strategic management: a stakeholders approach. Boston, MA: Pitman.

Gillwald, A. (2005). Good intentions, poor outcomes: Telecommunications reform in South Africa. Telecommunications Policy, 29(7), 469-491. doi:10.1016/j.telpol.2005.05.005

Glass, R., \& Vessey, I. (1995). Contemporary application-domain taxonomies. IEEE Software, 12(4), 63-76. doi: $10.1109 / 52.391837$

Hanafizadeh, P., Khosravi, B., \& Badie, K. (2019). Global discourse on ICT and the shaping of ICT policy in developing countries. Telecommunications Policy, 43(4), 324-388. doi:10.1016/j.telpol.2018.09.004

Howlett, M., McConnell, A., \& Perl, A. (2016). Moving policy theory forward: Connecting multiple stream and advocacy coalition frameworks to policy cycle models of analysis. Australian Journal of Public Administration, 76(1), 65-79. doi:10.1111/1467-8500.12191

Howlett, M., McConnell, A., \& Perl, A. (2016). Moving Policy Theory Forward: Connecting Multiple Stream and Advocacy Coalition Frameworks to Policy Cycle Models of Analysis. Australian Journal of Public Administration, 76(1), 65-79. doi:10.1111/1467-8500.12191 
Jann, W., \& Wegrich, K. (2007). Theories of the policy cycle. In Handbook of public policy analysis: Theory, politics, and methods (pp. 43-62). Routledge,

Janssen, M., \& Helbig, N. (2018). Innovating and changing the policy-cycle: Policy-makers be prepared! Government Information Quarterly, 35(4), S99-S105. doi:10.1016/j.giq.2015.11.009

Jorgenson, D., \& Vu, K. (2016). The ICT revolution, world economic growth, and policy issues. Telecommunications Policy, 40(5), 383-397. doi:10.1016/j.telpol.2016.01.002

Kamba, M. (2013). Information and Communication Technology (ICT) Policy for rural community development in Nigeria: A Blue print formulation without implementation. Information Manager (The), 13(1-2), 21-29.

Labelle, R. (2005). ICT Policy formulation and e-strategy development: A comprehensive guidebook. Amsterdam: Elsevier.

Lal, K. (2017). Investigating ICT infrastructure to develop an information society in India. Universal Access in the Information Society, 16(2), 517-528. doi:10.1007/s10209-016-0472-1

Lewis, C. (2013). Universal access and service interventions in South Africa: best practice, poor impact: challenges in leadership of ICT policy and e-development. The African Journal of Information and Communication, (13), 95-107.

Lindquist, E. (2006). Organizing for policy implementation: The emergence and role of implementation units in policy design and oversight. Journal of Comparative Policy Analysis, 8(4), 311-324. doi:10.1080/13876980600970864

Loblich, M., \& Wendelin, M. (2012). ICT policy activism on a national level: Ideas, resources and strategies of German civil society in governance processes. New Media \& Society, 14(6), 899-915. doi: $10.1177 / 1461444811432427$

Lubua, E., \& Maharaj, M. (2012). ICT policy and e-transparency in Tanzania. In Proceedings of IST-Africa conference (pp. 1-10). Academic Press.

Luyet, V., Schlaepfer, R., Parlange, M., \& Buttler, A. (2012). A framework to implement stakeholder participation in environmental project. Journal of Environmental Management, 111, 213-219. doi:10.1016/j. jenvman.2012.06.026 PMID:22926750

Makoza, F. (2019). Critical mass of women legislators and oversight for national ICT policy of Malawi. In Gender and Diversity: Concepts, Methodologies, Tools, and Application (pp. 950-970). Hershey, PA: IGI Global. doi:10.4018/978-1-5225-6912-1.ch048

Makoza, F., \& Chigona, W. (2016). Ex-post stakeholder analysis of national ICT policy subsystem. International Journal of ICT Research in Africa and the Middle East, 5(1), 15-34. doi:10.4018/IJICTRAME.2016010102

Mansell, R. (2014). Power and interests in Information and communication and development: Exogenous and endogenous discourses in contention. Journal of International Development, 26(1), 109-127. doi:10.1002/jid.1805

Marcelle, G. (2000). Getting gender into African ICT policy: A strategic review. In E. Rathgeber \& E. Adera (Eds.), Gender and information revolution in Africa. International Development Research Centre. Canada: IDRC.

Marsh, D., \& McConnell, A. (2010). Towards a framework for establishing policy success. Public Administration, 88(2), 564-583. doi:10.1111/j.1467-9299.2009.01803.x

Mashinini, M. (2008). Challenges of ICT policy for rural communities: A case study from South Africa. In Proceedings of the IFIP International Conference on Human Choice and Computers (pp. 125-137). Springer. doi:10.1007/978-0-387-84822-8_9

Matland, R. (1995). Synthesizing the implementation literature: The ambiguity-conflict model of policy implementation. Journal of Public Administration: Research and Theory, 5(2), 145-174.

Mehrizi, M., Ghasemzadeh, F., \& Molas-Gallart, J. (2009). Stakeholder mapping as an assessment framework for policy implementation. Evaluation, 15(4), 427-444. doi:10.1177/1356389009341731

Meyers, M. K., Vorsanger, S., Peters, B. G., \& Pierre, J. (2007). Street-level bureaucrats and the implementation of public policy. In The handbook of public administration (pp. 153-163). Sage. 
Mitchell, R., Agle, B., \& Wood, D. (1997). Towards a theory of stakeholder identification and salience: Defining the principle of who and what really counts. Academy of Management Review, 22(4), 853-886. doi:10.5465/ amr.1997.9711022105

Munyua, A. (2016). Exploring the multi-stakeholder experience in Kenya. Journal of Cyber Policy, 1(2), $206-221$. doi:10.1080/23738871.2016.1249898

Mwakatumbula, H., Moshi, G., \& Mitomo, H. (2019). Consumer protection in the telecommunication sector: A comparative institutional analysis of five African countries. Telecommunications Policy, 43(7), 1-8. doi:10.1016/j. telpol.2019.02.002

Nickerson, R., Varshney, U., \& Muntermann, J. (2013). A method for taxonomy development and its application in information systems. European Journal of Information Systems, 22(3), 336-359. doi:10.1057/ejis.2012.26

Pahl-Wostl, C. (2002). Participative and stakeholder-based policy design, evaluation and modelling processes. Integrated Assessment, 3(1), 3-14. doi:10.1076/iaij.3.1.3.7409

Poel, M., \& Kool, L. (2009). Innovation in information society policy: Rationale, policy mix and impact in The Netherlands. Info, 11(6), 51-68. doi:10.1108/14636690910996713

Poel, M., Kool, L., \& Giessen, A. (2010). How to decide on the priorities and coordination of information society policy? Analytical framework and three case studies. Info-The journal of policy, regulation and strategy for telecommunications, 12(6), 21-39.

Pulzl, H., \& Treib, O. (2007). Implementing public policy. In F. Fischer, G. Miller, \& M. Sidney (Eds.), Public policy analysis: Theory, politics and methods (pp. 89-104). New York: Taylor \& Francis Group.

Reed, M. (2008). Stakeholder participation for environmental management: A literature review. Biological Conservation, 141(10), 2417-2431. doi:10.1016/j.biocon.2008.07.014

Reed, M., \& Curzon, R. (2015). Stakeholder mapping for the governance of biosecurity: A literature review. Journal of Integrative Environmental Sciences, 12(1), 15-38. doi:10.1080/1943815X.2014.975723

Reed, M., Graves, A., Dandy, N., Posthumus, H., Hubacek, K., Morris, J., \& Stringer, L. C. (2009). Who's in and why? A typology of stakeholder analysis methods for natural resource management. Journal of Environmental Management, 90(5), 1933-1949. doi:10.1016/j.jenvman.2009.01.001 PMID:19231064

Rowley, J. (2011). e-Government stakeholders - Who are they and what do they want? International Journal of Information Management, 31(1), 53-62. doi:10.1016/j.ijinfomgt.2010.05.005

Schmid, L. (2009). Africa harnessing a broadband boom. I-WAYS. Digest of Electronic Commerce Policy and Regulation, 32(4), 219-227.

Sein, M., \& Harindranath, G. (2004). Conceptualizing the ICT artifact: Toward understanding the role of ICT in national development. The Information Society, 20(1), 15-24. doi:10.1080/01972240490269942

Singh, S. (2010). The South African 'Information Society', 1994-2008: Problems with policy, legislation, rhetoric and implementation. Journal of Southern African Studies, 36(1), 209-227. doi:10.1080/03057071003607444

Srivastava, A., Verma, P., \& Tripathi, A. (2017). Transformation and business emergence of Indian ICT sector with reference to Indian ICT policies. Transformation, 2(6), 449-452.

Stahl, B., \& McBride, N. (2009). Development and emancipation: The information society and decision support systems in local authorities in Egypt. Journal of Information. Communication and Ethics in Society, 8(1), 85-107. doi:10.1108/14779961011024828

Twaakyondo, H. (2011). Key issues in information communication technology policy review process: The case of Tanzania. Journal of Computing and ICT Research, 5(2), 46-58.

Varshney, U., Nickerson, R., \& Muntermann, J. (2013). Taxonomy development in Health-IT. In Proceedings of the Nineteenth Americas Conference on Information Systems (pp. 1-10). Academic Press.

Villanueva-Mansilla, E. (2016). Planning without Impacts: Assessing ICT Policies in Peru. Communication and Information Technologies Annual, 12, 181-206. doi:10.1108/S2050-206020160000012011 
Webster, J., \& Watson, R. (2002). Analyzing the past to prepare for the future: Writing a literature review. Management Information Systems Quarterly, 26(2), iii-xiii.

Weible, C., \& Sabatier, P. (2007). A guide to the advocacy coalition framework. In Handbook of public policy analysis: theory, politics, and methods (pp. 123-136). Routledge.

Frank Makoza is a Lecturer in the Department of Entrepreneurship and Business Management at Cape Peninsula University of Technology, Cape Town, South Africa. He holds a PhD in Information Systems and Master's degree in Information Systems from University of Cape Town. His research interests are assessing societal impact of ICT in context of developing countries and ICT use in small businesses. 